\title{
The Understanding of Friday Prayer Attendees (Mustamik) Towards Friday Sermon Discourse
}

\author{
Fahruroji, Moh. Rakhmat, Muhammad Shodiq \\ \{fahruroji@uninus.ac.id ${ }^{1}$, emrakhmat@gmail.com ${ }^{2}$, muhammadshodiq@gmail.com ${ }^{3}$ \} \\ University of Islamic Nusantara, Bandung, Indonesia ${ }^{1,2,3}$
}

\begin{abstract}
Discourse discussions have not received much attention from linguists, even though discourse is a cluster of sentences that has a communicative information unit. Discourse analysis reached a new stage of development in the 1970s. Language studies include grammar and meaning that need to be supported by context in a communication process. The process of communication will succeed if it meets the universal pragmatic requirements, specifically cognitive understanding, statement validity, honesty of speaker and listener, and conformity with the normative bases of the speakers. The method used in this research is descriptive. The source data are khotib or preachers who preach in the cities of Bandung and their surrounding areas and mustamik or Friday prayer attendees who at that time listen to the sermon. This research is expected to give an overview of how the mustamik or comprehend the sermons delivered by the khotib. Results show that most of the mustamik $(69.57 \%)$ said that they actually understand the khutbah discourse delivered by the khotib. The mustamik comprehension to the khutbah will be used as a representative model in making the text of the Friday khutbah in accordance with the results found in the study.
\end{abstract}

Keywords: Discourse Understanding, Friday Sermon, Friday Prayer Attendees

\section{Introduction}

It is no exaggeration to say that the study of discourse in Indonesia has not received sufficient attention. [1] says that discussion and discourse analysis is a relatively new field and still lacks the attention of linguists in general. Since the discussion of discourse is in fact perpetrated by sociologists, anthropologists, and philosophers, not by linguists.

Mentions that experts argue that discourse is a cluster of sentences that has a communicative information unit [2]. Until the late sixties, the discourse analysis had not received much attention from linguists. Discourse analysis reached a new stage of development in the 1970s. Firth (1935) is a linguist who first advocates discourse study. Through his idea, he mentions that the context of the situation needs to be studied by linguists because language studies and language work are in context. The study of language cannot be done if only depends on linear arrangements. Language studies include grammar and meaning.

The study of discourse is actually the most complete language element when it is viewed in terms of its completeness. Discourse is not only supported by segmental elements of a language such as sentence, morpheme, phoneme, but also supported by non-congruent elements, such as space, situations, time of use, purpose of language usage, language user, intonation, pressure, meaning, and feelings of language. Without these elements, discussion of discourse cannot proceed as expected. 
States that in terms of function as the basis of epistemology, separating subject from the object and encouraged the empiricists to restrict scientific analysis or study is solely within the framework of accuracy of measurement [3]. Discourse is then measured by considerations of truth and its untruth (according to syntax and semantics), but not on the basis of whatever resources that it can produce or to whom it is directed.

Furthermore, within the framework of the epistemology of key phenomenology in seeking the link between language and social action is inter subjectivity. Because through this relationship, the formation of meaning, including the establishment of social reality (the social construction of reality), is continuously conducted by members of the community.

Subjectivity and agency, with no doubt, have become the main starting point for phenomenologists to understand social discourse. Language, in their hands, is not only acceptable as it is, but is regarded as an intermediary for the disclosure of certain intents and meanings. To them, discourse is an attempt to reveal the hidden intentions of the subject which expresses a statement. So it makes sense to say that "to understand the creator better than he understands himself is by (showing) the implicit expression forces in the discourse beyond the horizon of his existence."

From that view it is known why interpretation as a method of disclosure of meaning contained in human discourses, behavior, and actions become so important in order to know the subjectivity and inter subjectivity earlier. According to Alferd Schutz, to be able to understand human actions well, we must also understand the basic motive by putting ourselves in the speaker's position. The pronunciation is unacceptable in spite of the fact that it has fulfilled syntactic and semantic rules. But it still needs interpretations following the structure of the speaker's meaning. It is only in this way that the symbolic relationship between the listener and the speaker can occupy a central position in order to reveal the hidden meaning of a discourse. From here, it is drawn to such annexes as ethnomethodology and symbolic interactions in social sciences, especially sociology and anthropology.

Geertz understands language as one of the cultural symbols that serves to provide orientation, communication and self-control to humans. Thus, for Geertz, language is not only understood in mere cognitive functioning, but more importantly in the capacity of producers and producers of social reality. To the extent that language is a symbolic production process, it is inseparable from the speaker's "intent". Social investigations with language and discourse should be done to bridge the gap between the text and its readers, so that at the end they can fully understand the intent of its "creator".

In addition to Geertz, Herbermas (1981) gives his theoretical addition to what has come to be called the theory of communicative action or theory of communicative competence that is the basis of his studies on Modern social problems, which is heavily influenced by his analysis of language and discourse. Herbermas emphasizes that the importance of inter subjectivity aspects in discourse processes. He primarily views language as a medium for connecting the subject with three areas, specifically the external region, the social realm, and the inner world. The first area refers to situations outside the community in which the subject is located. The second area refers to the totality of interpersonal relationships that have normative rules in society. While the third area, refers to the totality of subjective intentions and experiences of the speaker.

For Hebarmas, discourse and communication transactions (communicative transactions) are attempts to find common ground and mutual understanding between participants. The process of communication, he argued only, would succeed if it fulfilled the universal pragmatic requirements, specifically cognitive understanding, validity of statement, honesty of speaker and listener, and conformity with the normative bases of the speakers. As a normative 
basis in the process of communication, these universal pragmatic elements are of course deeply influenced by external dimensions such as economic systems, social formations, and the degree of evolution of society in which the subject lies. The practical implication is that only in the context of a rational and "matured" society, a truly meaningful communication can take place.

According to Epstein (1961), in the level of discourse, which is greater than the sentence, we can place the sentence at a level approximately equal to "movement". At the level of discourse which is especially done in the classroom, the highest level is "lesson", then the next level is "transaction", next is "exchange", then it is "movement", and finally the lowest is "action".

Indonesia as a predominantly Muslim country, of course, whose citizens are carrying out their religious obligations, one of the obligations that must be executed is the Friday prayer. Friday prayer which is held once a week must be preceded by "Two Khutbah" delivered by a sermon. Submission of the sermon to the attendees is the delivery of discourse in which there are "penyapa" (greeter) and "pesapa" (people who are greeted).

The discourse given by khotib becomes very important because the attendees must listen to it well so that the messages conveyed by the khotib can be a lesson to be able to increase their devotion to Allah SWT. Khotib delivers his discourse in oral form. Oral discourse that emphasizes "content" can be speech, lecture, preaching, preaching, lecture, or reclamation. Besides "content", "language" as a tool to convey messages is not separated into attention. This is the focus of the author's study to uncover the discourse model of Friday's Sermon and the extent to which the Friday Prayers attendees understand the discourse.

In general, the purpose of this study is to determine the general condition of khutbah discourse delivered by khotib at the time of Friday prayers. While in particular, this study aims to find out more about the discourse of the sermon delivered by khotib. Then, it is hoped that the description of the Friday sermon discourse can be obtained in accordance with the guidance of the worship and the demands of the development of society. It is also to know the response of the attendees whether they understand the Friday sermon preached by the khotib or not.

In general, on the basis of the facts already mentioned in the introduction above, and the purpose and urgency of this study can be expressed by the formulation, "How is the model of the sermon preached by khotib?" Specifically, this research tries to answer the problems below.

1. In what situation does the preacher preach his sermon?

2. Does the preacher propose the "Title" or "Theme" of the sermon he will deliver?

3. Does the preacher convey the discourse of the sermon according to the context?

4. Is the discourse of the sermon delivered by the khotib can be understood by the congregation (mustamik)?

5. Is the time spent by preacher at the time of preaching conforms to the wishes of the Mustamik?

6. Did the khotib in preaching his sermon prepare the text of the sermon?

This study will contribute positively to the development of khotib mastery on the material to be delivered at the time of the sermon, so that the message conveyed to the khotib can be understood. Listening to the sermon well is mandatory, so that if someone says a word to his friend, it already includes as ignoring the sermon. Therefore, this study would like to reveal the empirical data that occurred about the understanding of preaching delivered khotib on real situation in the implementation of Friday Khutbah. 


\section{Literature Review}

The main term used in this study is the understanding of the discourse of Friday sermon by mustamik. Theoretically, the meaning of the discourse and its analysis will be explained as follows.

\subsection{Discourse}

Discourse is a complete linguistic recording of communication events [4]. Discourse is also the most complete unit, which in the grammatical hierarchy is the highest unit, realized in the form of a complete discourse (novels, books, etc.), paragraphs, sentences, or words that carry the complete message [5]. Likewise, [6] mentions that discourse is the most complete and highest or highest language unit above a sentence or clause with continuous high coherence and cohesion that has a real beginning and end, and it is delivered orally or written.

In the context of discourse-critical, [7] argues that discourse analysis is a type of discourse analytical research that primarily studies the way social power abuse, dominance and inequality are enacted, reproduced and resisted by text and talk in the social and political context. With such dissident research, critical discourse analysts take explicit position, and thus want to understand, expose and ultimately to resist social inequality. What is meant by discourse analysis in this study is that a critical analysis of the overall discourse contained in sermons and books of sermon collection in order to analyze whether the discourses are related to behavioral changes or not.

Fairclough \& Wodak (1997: 55) mention that critical discourse analysis views discourse the use of language in speech and writing - as a form of social practice. Explaining discourse as a social practice implies a dialectical relationship between a particular discursive event with its situations, the institutions, and the social structure that embodies it. A dialectical relationship is a two-way relationship: discursive events are shaped by situations, institutions and social structures. The events also form all three. From the complex relationships between language and social facts, it is found out that the ideological effects are often unclear and hidden in the use of language as well as the influence of power reliance.

\subsection{Content Analysis}

Content analysis is one of the research techniques to describe communication messages objectively, systematically, and quantitatively. Mentions that content analysis is a method for observing and measuring the content of communication [8]. Quoting Kerlinger (1973: 525), Flournoy reveals that instead of observing people's behavior directly or asking them to respond to scales, or interviewing them, the investigator takes the communications that people have produced and asks questions of the communication. In the meantime, communication experts from Ohio University, [9] defines content analysis as a formal system for doing something that we all do informally rather frequently, drawing conclusions from observations of content.

Although this content analytical approach is more widely used in the context of Communication Science to analyze the contents of mass media, the approach can also be adopted into the Language Science with little change. In this research, content analysis is the analysis of the content of the sermon. It analyzes the material or topic to be presented, the presentation, the use of the language, or the message to be conveyed. 


\subsection{Language Analysis}

As we know that language is composed of phonemes, morphemes, phrases, clauses, sentences, and paragraphs. Such composition has been studied for centuries by mankind, then three major streams in linguistics emerges. The three major streams are traditionalism, structuralism, and generative transformation. The generative transformation emerged in 1957 after Chomsky had published his book Generative Transformational Grammar. This stream displays generative ideas, and this goes against the flow of distributions (Lubis, 1991: 15).

Language analysis lies in the linguistic side. Therefore, his analysis uses the framework of linguistic theories, specifically paragraphs, sentences, phrases, morphemes, and phonemes. Has the language usage conformed to these rules?

\subsection{Friday Sermon}

Friday's sermon is the two sermons delivered by a sermon as part of the Friday prayer requirement. Friday sermon is delivered before the Friday prayer on the condition that they must be sequential, i.e. khutbah first then just do the Friday prayer.

The sermon should be understood by its attendees (mustamik). Therefore, it will have a positive impact on the mustamik, and it can change their behavior in everyday life. The khotib should pay attention to his sermon to make his khutbah understandable by the attendees.

The author found 3 studies related to the discourse of the Friday Khutbah. First, a sociolinguistic study conducted by [10] which discusses the type of code and function of the discourse of the Friday sermon discourse. This study focuses on the type and function of the code used in the Friday Khutbah discourse, but it does not discuss whether the discourse of delivered Friday sermon is understood by the congregation or not. The second study was conducted by [11] with the title "Discourse on Friday's Sermon in Surakarta: A Cultural Linguistic Study". This study focuses on cultural linguistic problems, but it does not expose the discourse of the Friday sermon or the understanding of its attendees. The third study was conducted by [12], entitled "The Form and Function of the Friday Khutbah Discourse Code". This research is almost identical to that the first study which addressed the problem of code type and function. These three studies are different with the research that the author do.

\section{Research Method}

\subsection{The Scope of Research}

As already known that in the discourse, there are greeter and greeted. In Friday prayer, khotib is as the "greeter" who conveys the sermon, and Friday prayer attendees are as the "greeted" who listen to the sermon. Therefore, the khotib and the Friday prayer attendees can be object of research. The source of this research data is the khotib who perform their sermons in different mosques and mustamik who attend the Friday prayers at mosques. The location of the mosque as the subject of research is located in Bandung cities and their surrounding areas. 


\subsection{Research Methods}

The research method used is descriptive method by emphasizing deep research on the problem under study. It is conducted in a caustic study to khotib and Friday prayers attendees in Friday Prayers.

\subsection{Data Collection}

Data collection tool used in this research are:

1. Direct observation of the moslems who attend the Friday prayers.

2. Interview to the mustamik who attend the Friday prayers also the khotib who have delivered the sermon.

3. The collected data are then examined and calculated in accordance with the results obtained from the responses of the khotib and mustamik. The data are then identified, analyzed, and interpreted.

4. The results of this interpretation are expected to answer research questions or formulation of problems that have been raised on the formulation of the problem.

5. Questionnaires are distributed to khotib and mustamik.

\subsection{Data and Data Sources}

The data used is the collection of questionnaires that have been filled by the khotib and mustamik, the results of interviews with them, and observations made at the time of Friday prayers. The data collected from the Friday Prayers are 23. These data are collected from different mosques, but some data are obtained from the same mosque in which four people became the research sample.

\section{Results And Discussion}

Data obtained from people who attend Friday prayer in the mosques that are used for Friday prayers. The name of the mosque and its address can be seen in the following table.

Table 1. Name and Address of the Mosques

\begin{tabular}{lll}
\hline No & Name of Mosques & \multicolumn{1}{c}{ Address of Mosques } \\
\hline 1 & Al-Mubarokah & Cibaduyut Bandung \\
2 & Umar bin Khotob & Nanjung Mekar Bandung \\
3 & Al-Ikhlas & Cipatat Buah Dua Sumedang \\
4 & Al-Hikmah & Soekarno Hatta Bandung \\
5 & Sirojussalam & Soekarno Hatta Bandung \\
6 & Miftahul Jannah & Congeang Sumedang \\
7 & Al-Ikhlas & Soekarno Hatta Bandung \\
8 & Al-Ikhlas & Soekarno Hatta Bandung \\
9 & Al-Ikhlas & Soekarno Hatta Bandung \\
10 & Al-Ikhlas & Soekarno Hatta Bandung \\
11 & An-Nur & Asia Afrika Bandung \\
12 & Nurrohman & Mengger Girang Bandung \\
13 & Al-Firdaus & Bandung Barat \\
14 & STT Mandata & Dewi Sartika Bandung \\
\hline
\end{tabular}




\begin{tabular}{lll}
\hline 15 & Al-Fatah & Ciherang Sukabumi \\
15 & Miftahul Barokah & Sukasenang Garut \\
17 & Al-Hidayah & Cikendal Sumedang \\
18 & Al-Burhan & Sirna Galih Bandung \\
19 & Al-Muawanah & Pusaka Jaya Subang \\
20 & Al-Mi'raj & Kp. Pancuran Bandung \\
21 & Madinah & Antapani Bandung \\
22 & Assolihin & Pungkur Bandung \\
23 & As-Suada & Mande Cianjur \\
\hline
\end{tabular}

The table above shows the mosques that become the object of research which are mostly in Bandung area. Some of the mosques are in the surrounding areas such as Subang, Sumedang, Garut, Cianjur, and Sukabumi.

The Friday prayers attendees who are willing to talk and fill out a questionnaire that has been provided are 23 people. The data obtained from these 23 attendees are discussed and analyzed. Their complete identities were not mentioned, this was done to maintain their privacy. The formal educational background of these 23 attendees can be seen in the following table.

Table 2. The Educational Background of Friday Prayers Attendees

\begin{tabular}{llcc}
\hline No & Academic Background & Frequency & Percentage \\
\hline 1 & SD/MI & 3 & 13 \\
2 & SMP/MTs & 2 & 8,70 \\
3 & SMA/SMK/MA & 13 & 56,52 \\
4 & PT & 5 & 21,74 \\
& Total & $\mathbf{2 3}$ & $\mathbf{1 0 0}$ \\
\hline
\end{tabular}

Table 2 above shows the educational background of Friday prayers attendees which is varied from elementary school/MI to university. The least is the SMP/MTs by $8.70 \%$, and the most are SMA/SMK/MA by $56.52 \%$, while the College is $21.74 \%$. This educational background will also show their level of understanding to what have been delivered by khotib in his sermon.

From the category of Friday prayer attendees' age, it is also varied. The youngest is 16 years old, and the oldest is 65 years old. The category of age can be grouped at intervals as follows.

Table 3. Age Classification Range of Respondents

\begin{tabular}{cccc}
\hline No & Range of Age & Frequency & Percentage \\
\hline 1 & $59-65$ & 2 & 8,69 \\
2 & $52-58$ & 0 & 0 \\
3 & $45-51$ & 3 & 13,04 \\
4 & $38-44$ & 3 & 13,04 \\
5 & $30-37$ & 3 & 13,04 \\
6 & $23-29$ & 8 & 34,78 \\
7 & $16-22$ & 4 & 17,39 \\
& Total & $\mathbf{2 3}$ & $\mathbf{1 0 0}$ \\
\hline
\end{tabular}

From the Table 3 above, it can be seen that the majority of respondents are between 23 29 years old by $34.78 \%$. Those who are between $16-22$ years old are $17.39 \%$, and those who are between 30 - 37 years old, $38-44$, and 45 - 44 years are $13.04 \%$. While the age of between 59 - 65 years is the least by $8.69 \%$. 
The sermons delivered by the khotib are certainly in formal and official situations. This is done because the discourse is different from ordinary speech in general. When the question of the formality and the inauguration of the khotib in giving their sermons was asked, all of the khotib $(100 \%)$ answered that their sermons is formal and official. This can be more clearly seen in Table 4 below.

Table 4. The Sermon Which Conveyed Formal and Official

\begin{tabular}{llcc}
\hline No & Situation & Frequency & Percentage \\
\hline 1 & Formal and Official & 23 & 100 \\
2 & Less Formal and Official & 0 & 0 \\
3 & Informal and not Official & 0 & 0 \\
4 & No Idea & 0 & 0 \\
& Total & $\mathbf{2 3}$ & $\mathbf{1 0 0}$ \\
\hline
\end{tabular}

This shows that in Friday prayer, the situation is formal and official. Therefore, khotib in delivering his sermon is formal and official. This is in accordance with the theory of language variation as proposed by Martin Joos (1967) which states that based on the level of formality variation, the language is divided into five kinds of styles, that is formal style, style or variety of business (consultative), casual style or variety (casual), and intimate style or variety (intimate). Furthermore, Chaer mentioned that formal or formal variations are variations of the language used in state speeches, official meetings, religious lectures, textbooks, and so on. The official pattern and rules are established as a standard.

In term of the language of instruction used by khotib, other than those required to use Arabic, can be seen as Table 5 below.

Table 5. Languages Which Used by Preacher

\begin{tabular}{llcc}
\hline No & Language & Frequency & Percentage \\
\hline 1 & Arabic & 5 & 21,73 \\
2 & Indonesia & 17 & 73,91 \\
3 & Sundanese & 1 & 4,35 \\
4 & Others & 0 & 0 \\
& Total & $\mathbf{2 3}$ & $\mathbf{1 0 0}$ \\
\hline
\end{tabular}

In term of the delivery of the title or theme of the sermon delivered by the sermon, or as in question of whether the khotib mentioned the title or theme to be delivered in his sermon, 11 attendees $(47.82 \%)$ responded that the title or theme was mentioned. This is in accordance with the attendees who said that the khotib did not mentioned the title or theme of his sermon. While attendees who said not know is only 1 person or by $4.34 \%$, and who said very not know does not exist. More details can be seen in Table 6 below.

Table 6. The Preacher Informed the Topic or Theme

\begin{tabular}{llcc}
\hline No & \multicolumn{1}{c}{ Situation } & Frequency & Percentage \\
\hline 1 & Conveying/Informing the Topic & 11 & 47,82 \\
2 & Not Conveying/Informing & 11 & 47,82 \\
3 & Not Sure & 1 & 4,34 \\
4 & No Idea & 0 & 0 \\
& Total & $\mathbf{2 3}$ & $\mathbf{1 0 0}$ \\
\hline
\end{tabular}

Answers to the questions concerning if the khotib prepared the discourse of the sermon in the form of a written text can be seen in Table 7 . 
Table 7. Preparation of Sermon Text Which Delivered

\begin{tabular}{llcc}
\hline No & \multicolumn{1}{c}{ Situation } & Frequency & Percentage \\
\hline 1 & Preparing the Text & 19 & 82,61 \\
2 & Not Preparing the Text & 1 & 4,34 \\
3 & Not Sure & 3 & 13,04 \\
4 & No Idea & 0 & 0 \\
& Total & 23 & 100 \\
\hline
\end{tabular}

If we look at the Table 7 above, it is clear that almost all of the khotib (82.61\%) prepared their sermon texts, and only $4.34 \%$ of them who did not prepare, and $13.04 \%$ of them said that they did not know. From this perspective, it can be said that if a khotib wants to deliver a sermon, he should prepare the material to be delivered to the attendees.

The asnwers to the question in term of the understanding of the attendees to the material or content of the sermon delivered by the khotib can be seen in Table 8 below.

Table 8. Understanding the material or content of the sermon

\begin{tabular}{llcc}
\hline No & \multicolumn{1}{c}{ Answer } & Frequency & Percentage \\
\hline 1 & Very Understand & 16 & 69,57 \\
2 & Understand & 2 & 8,60 \\
3 & Not Understand & 5 & 21,74 \\
4 & Very Unfamiliar & 0 & 0 \\
& Total & 23 & 100 \\
\hline
\end{tabular}

Table 8 above illustrates that most of the attendees by $69.57 \%$ said that the material or content delivered by khotib was certainly understandable. $8.60 \%$ of the attendees stated that they understood. $21.74 \%$ of the attendees said that they did not understand. No attendees answered with not understand.

The answers to the question of the sermon duration delivered by the khotib of whether the sermon has been in accordance with the expectations of the mustamik or not can be seen as in Table 9 below.

Table 9. Conformity of Time with expectations of Congregation

\begin{tabular}{llcc}
\hline No & Answer & Frequency & Percentage \\
\hline 1 & Appropriate & 19 & 82,61 \\
2 & Inappropriate & 2 & 8,69 \\
3 & Not Sure & 2 & 8,69 \\
4 & No Idea & 0 & 0 \\
& Total & 23 & 100 \\
\hline
\end{tabular}

Table 9 above shows that $82.61 \%$ or almost all of the attendees stated that the duration of sermon are in accordance with expectations. 8.69\% of the attendees stated that the duration are not in accordance. $8.69 \%$ of the attendees stated that they did not know. It can be interpreted that the expectations about the sermon duration of the attendees have been fulfilled.

The answers to the question of what the ideal length of time according to the attendees can be seen in Table 10 .

According to the attendees, as can be seen in Table 10 above, the ideal time to deliver Friday sermons is between 15 - 20 minutes. It is answered by $65.21 \%$ of the attendees. It means that most of the attendees expect the sermon to be delivered in $15-20$ minutes. Those who expect 21 - 25 minutes are $13.04 \%$ and those who expect $26-30$ minutes are $17.39 \%$. Those who expect more than 30 minutes are only $3.34 \%$. This is consistent with the Prophet 
Muhammad saw does that he shortened the sermons and prolonged the prayer as in the Hadith which states that the actual long prayer and short sermon is a sign of khotib scholarship (H.R. Muslim no 869). How many minutes are considered short is answered by the response of Friday prayers attendees or mustamiin that is 15-20 minutes.

Table 10. Ideal Time Spending for Sermon

\begin{tabular}{llcc}
\hline No & \multicolumn{1}{c}{ Time Range } & Frequency & Percentage \\
\hline 1 & $15-20$ minutes & 15 & 65,21 \\
2 & $21-25$ minutes & 3 & 13,04 \\
3 & $26-30$ minutes & 4 & 17,39 \\
4 & More than 30 minutes & 1 & 3,34 \\
& Total & 23 & 100 \\
\hline
\end{tabular}

\section{Conclusion}

After discussing the data collected from the respondents in the Friday prayers and doing the analysis of the data, it can be concluded that the sermon delivered by the khotib is in line with the expectations of most worshipers Friday prayers. Most of them also say that the sermon delivered by the khotib can be understood. The duration of the ideal sermon according to the attendees is 15 - 20 minutes. It shows that short duration of sermon delivery will be both effective and understandable by the Friday prayers attendees.

Therefore, the sermons of the discourse that will be delivered to the attendees should not be too long and use formal and official language, as well as are easily understood, so that the message delivered by the khotib can be understood by the Friday prayers attendees. Messages that have been delivered by the khotib and can be understood by the attendees are expected to have a positive influence on them.

\section{References}

[1] Syamsuddin, "Studi Wacana Kajian Linguistik Komprehensif," in Pidato Pengukuhan Jabatan Guru Besar dalam Ilmu Kebahasaan pada Jurusan Pendidikan Bahasa Indonesia FPBS IKIP Bandung, 1999.

[2] T. F. Djajasudarma, Wacana Pemahaman dan Hubungan Antarunsur. Bandung: Refika Aditama, 2006.

[3] M. Shapiro, Language and Political Understanding: The Politics of Discursive Practice, Haven. Yale Universitiy, 1981.

[4] Samsuri, Analisis Wacana. IKIP Malang, 1987.

[5] H. Kridalaksana, Kamus Linguistik. Jakarta: Gramedia, 1984.

[6] H. . Tarigan, Pengajaran wacana. Bandung: Angkasa, 1987.

[7] T. A. Van Dijk, News as discourse. Hillsdale, NJ: Erlbaum, 1988.

[8] D. M. (Ed. . Flournoy, Content analysis of Indonesia Newspapers. Yogyakarta: Gadjah Mada University Press., 1992.

[9] G. Stempel, Research Method in Mass Comunication. ohio: Prentice Hall, 1981.

[10] A. Ma'ruf, "Jenis Kode dan Fungsi Kode yang Digunakan dalam Wacana Khotbah Jumat, suatu Kajian Sosiolinguistik,” UGM Yogyakarta, 1999.

[11] K. Sadhono and I. D. P. Wijana, "Wacana Khotbah Jumat di Surakarta, suatu Kajian Linguistik Kultural," UNS.

[12] Suharyo, "Bentuk dan Kode Wacana Khutbah Jumat," Universitas Diponegoro Semarang, 2012. 